\title{
The Application of Flexibility Concept on East Java's Art Auditorium
}

\author{
Galuh Fajarwati, Asri Dinapradipta, Vincentius Totok Noerwasito \\ Department of Architecture, Institut Teknologi Sepuluh Nopember, Surabaya \\ e-mail: asdina_parch.its.ac.id
}

\begin{abstract}
Abstrak - East Java art has a diversity of types and forms of performances. There are types of performances in the form of theatrical and ballet performances. This traditional art performance is intended to convey messages, advice, and past stories. This presentation is presented with various types of art so that between the types of theatrical or dance performances, each has a variety of needs for its stage and capacity. However, the lack of staging facilities is one of the problems that result in reduced artistic activities, so that some traditional arts in East Java are threatened with extinction. In this study, the purpose of this study is to look for patterns of flexibility in the auditorium to meet the needs of East Java art activities. The method used is the observation method. The observation was carried out by observing each type of East Java art activities to be accommodated, namely the type of traditional dance and theater. The selected arts are several art representatives who have the same type of performance. From the results of data analysis it can be concluded that the auditorium can at least adapt to 4 types of spatial configurations: arena, endstage, proscenium, and plaind stage.
\end{abstract}

Kata Kunci-Auditorium, Flexibility, Traditional.

\section{INTRODUCTION}

$\mathrm{T}_{\mathrm{s}}$ HIS research is a part of the traditional Javanese art building design process that uses a flexible approach. This study aims to determine the flexibility criteria that can be carried out by the auditorium with the need to perform traditional arts in East Java. The application of the concept of flexibility will be used in this auditorium room because the traditional arts of East Java have various types of performances. The diversity of traditional Javanese arts in theater, dance, and music. The diversity of this type of art affects the type of activity and the needs of the space that must be contained.

In the first phase of this journal, we will discuss the flexibility method that will be applied. The type of space flexibility that will be applied is chosen and adjusted to the needs of traditional arts. At a later stage, the selection of art will be evaluated in which art is one of the representatives of this type of art that has the type of staging or a different presentation. Then the evaluation is done by grouping the arts that have similar types of staging needs and determining the number of types of spatial changes that must occur in the auditorium.

At the end of the journal, conclusions are drawn from the findings and analyses that have carried out. The conclusion will be in the form of a characteristic space auditorium concept of flexibility that has an adaptation based on the traditional arts of East Java.
Table 1.

Classification of traditional Javanese dance art

\begin{tabular}{|c|c|c|c|}
\hline $\begin{array}{l}\text { The name of } \\
\text { art }\end{array}$ & $\begin{array}{l}\text { Number of } \\
\text { activists }\end{array}$ & $\begin{array}{l}\text { Accompany } \\
\text { music }\end{array}$ & Stage form \\
\hline A. Remo & $>1$ person & Gamelan & Endstage \\
\hline Jaranan buto & $16-20$ person & Gamelan & Arena \\
\hline $\begin{array}{l}\text { Giri Gora } \\
\text { Dahuru Daha }\end{array}$ & 5 person & person & Arena \\
\hline $\begin{array}{l}\text { Kiprah } \\
\text { Glipang }\end{array}$ & $>5$ person & $\begin{array}{l}\text { Musik } \\
\text { Glipang }\end{array}$ & Arena \\
\hline Gandrung & $>1$ person & $\begin{array}{l}\text { Gendang, } \\
\text { rebana }\end{array}$ & Endstage \\
\hline $\begin{array}{l}\text { 1) Kethek } \\
\text { Ogleng }\end{array}$ & 4 person & Gamelan & Endstage \\
\hline 2) Lahbako & $>4$ person & Ppatrol & Endstage \\
\hline Beskalan & $>2$ person & $\begin{array}{l}\text { laras } \\
\text { slendro }\end{array}$ & Proscenium \\
\hline
\end{tabular}

Table 2.

Classification of traditional Javanese drama arts

\begin{tabular}{llll}
\hline \hline $\begin{array}{l}\text { The name of } \\
\text { art }\end{array}$ & $\begin{array}{l}\text { Number of } \\
\text { activists }\end{array}$ & Accompany music & Stage form \\
\hline Kethoprak & $\begin{array}{l}\text { Appropriate } \\
\text { drama }\end{array}$ & Gamelan & Proscenium \\
Ludruk & $\begin{array}{l}\text { Appropriate } \\
\text { drama }\end{array}$ & Gamelan & Proscenium \\
$\begin{array}{l}\text { Dalang, } \\
\text { Timplong }\end{array}$ & pengiring & Gamelan & Proscenium \\
$\begin{array}{l}\text { C. Wayang } \\
\text { Topeng }\end{array}$ & 6 person & Karawitan/Gamelan & Proscenium \\
\hline \hline
\end{tabular}

\section{METHOD}

In this study, the method used is qualitative. Data collection is done by field observations and descriptive research by the data needed in this study and also is open in nature that allows the addition of new ideas that are relevant to research [1]. The process of gathering information in this study is done by searching the literature, using images for observation and visual analysis, interviews, and observations of similar objects.

Observations were made to some of the East Javanese traditional performance activities and to observe the literature data of each type of traditional East Javanese art that will be examined, namely the types of theater, dance, and music. Observation is done by observing all the staging activities.

The first thing to do is to analyze the actors of each type of activity, number, and activities. Furthermore, describe each activity carried out so that the needs obtained from the performance space. Second is to do overlapping of each activity so that similarities and types of changes needed in the 
The $6^{\text {th }}$ International Seminar on Science and Technology (ISST) 2020

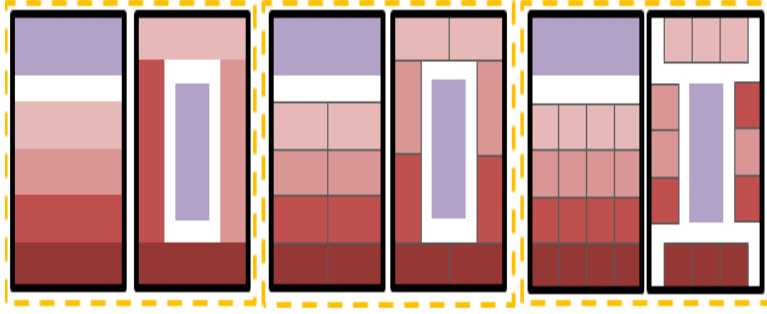

Figure 1. Alternative changes that can occur in square space.

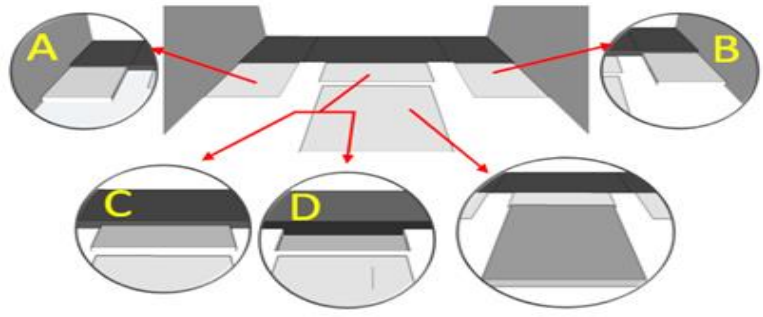

Figure 2. (A) Requirement left music stage (stage); (B) The need for the right music stage (stage); (C) The need for a musical stage front and center; (D) The need for mid-stage down the stage.

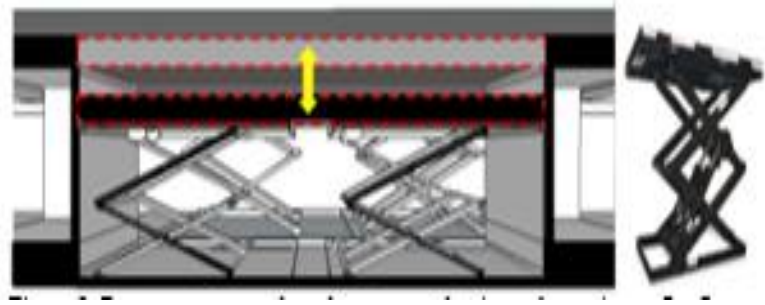

Figure 3 . Rostra system used on the stage so that into a flat floor and into a stage show.

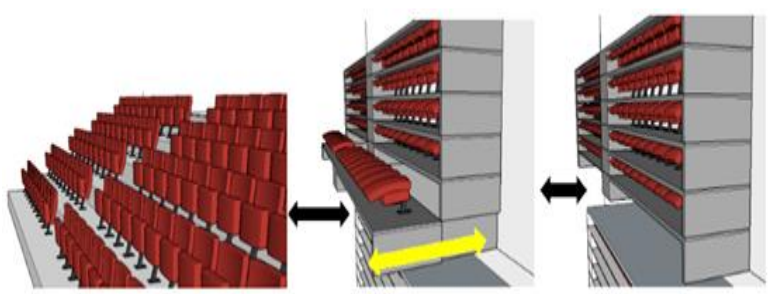

Figure 4. Movement of seat elements that can be stored.

auditorium can be found to achieve the flexibility of space required for the performance of traditional arts in East Java.

In a building, flexibility is exercised to respond to changing situations in use, operation, or location. This is an architecture that adapts, sustains, interacts with users rather than impedes, and serves as a reason for contemporary problems related to technological, social, and economic changes [2]. Flexibility has a special category of building flexibility types which have been identified as follows: Adaptable, Movable, Responsive, Transformable [2-3]. The basis of the flexibility analysis of this traditional art auditorium uses the concept of flexibility by strong in his book Theater Building a Design Guide [4]. The usual areas where some form of adaptability is introduced are:

1. Orchestra pit and forestage zone

2. Variable audience capacity

3. Adjustable proscenium width and height

4. Adjustable acoustics

5. Format change and variable formats.

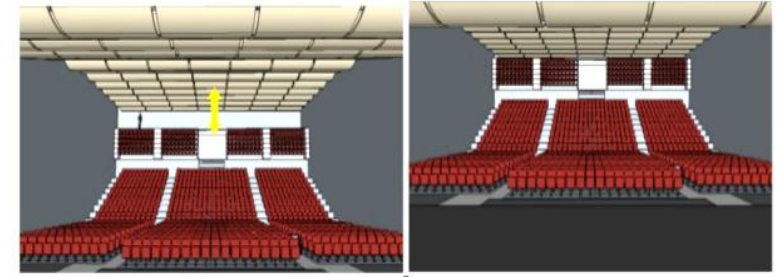

Figure 5. Movement of adjustable ceiling elements.

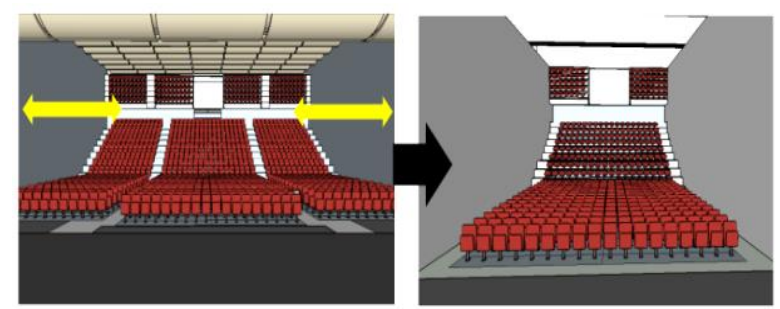

Figure 6 . The right and left walls of the auditorium that can be moved.

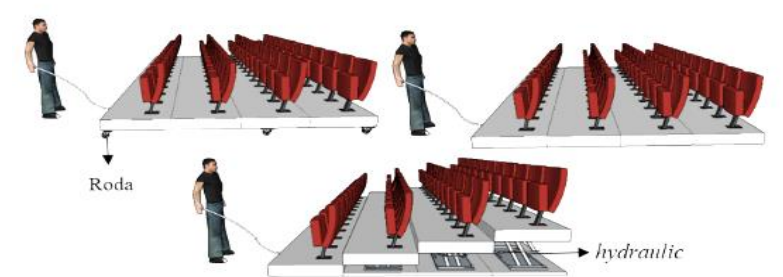

Figure 7. The process of changing the configuration of a flat seat unit into a ladder.

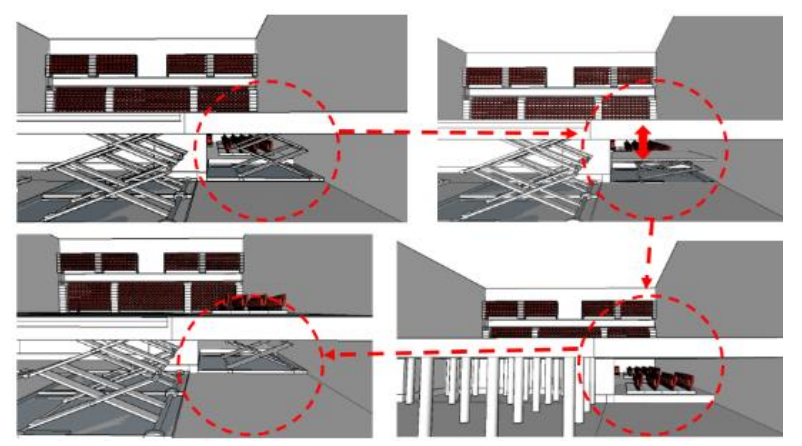

Figure 8 . The process of moving the seat unit that can be moved and stored.

\section{RESULTS AND DISCUSSION}

\section{A. The Classification of East Java Arts}

East Java art consists of several types of art, namely theater, dance, music or Sinden, and crafts or painting. Traditional art that would be a consideration in the design of the traditional auditorium of East Java are dance and theater arts from several regions in East Java. Here are some of the arts of the East Java region and classification in their performance can see Table 1 and Tabel 2.

From the results of the analysis of the types of performances from several selected dance stations, they have a variety of stage types used, namely: endstage, arena, and proscenium. Whereas East Javanese art requires stage types with endstage and proscenium types. With the accompaniment music area having separate stages in the front, right or left side of the stage. Data standardization of public theater form and number of seats according to the type 
The $6^{\text {th }}$ International Seminar on Science and Technology (ISST) 2020

July $25^{\text {th }} 2020$, Institut Teknologi Sepuluh Nopember, Surabaya, Indonesia

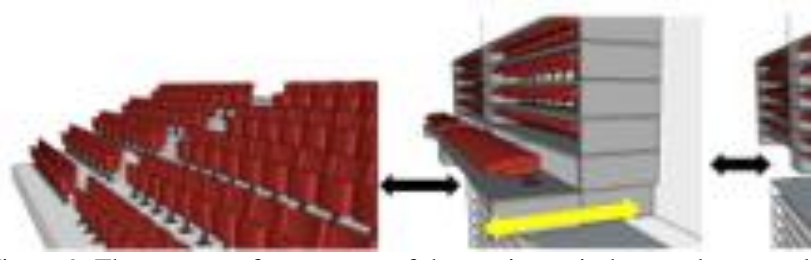

Figure 9. The process of movement of the seating unit that can be set and arranged according to the needs of the type of staging.

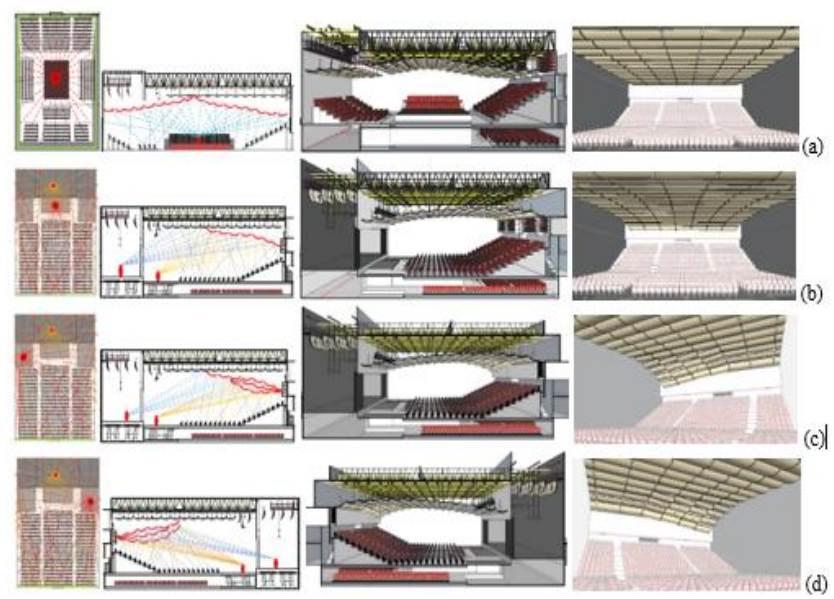

Figure 10. the movement of the ceiling elements adjusts the acoustic requirements of space. (a) Sound source comes from the sound system. (b) Sound source comes from the center of the stage. (c) Sound source comes from the right of the stage. (d) Sound source comes from the left of the stage.

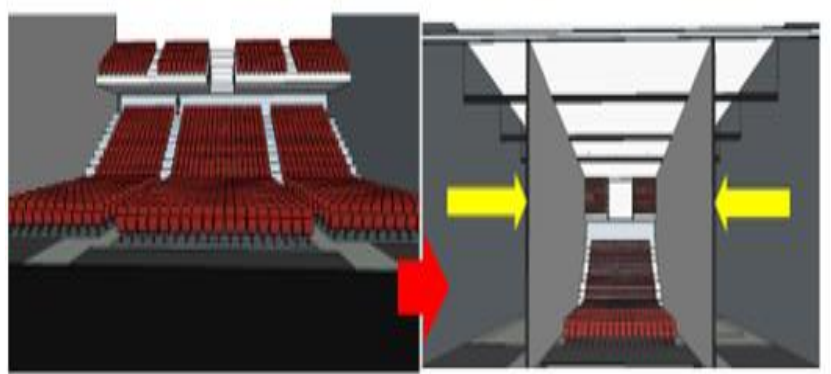

Figure 11. The process of moving the walls of the auditorium room to adjust the space requirements as needed.

of performance, namely: endstage up to 500 person, arena up to 700 person, and proscenium up to 1,100 person [5], the amount of capacity each type of staging different forms according to the type of stage. So the change in room size is one thing that must be met.

The needs of the musician area in East Java art also have differences with modern art, so adjusting the area of the art area must also be adjusted to the capacity and the needs of East Java traditional arts both the number of actors and the size of musical instruments. From the results of the analysis, it can be concluded the extent of each type of stage can accommodate following the minimum capacity of the audience and can make changes to the area of space as needed. Three alternative forms of stage is endstage, arena, and proscenium.

\section{B. Types of Basic Formations of the Auditorium Room}

An alternative analysis of the auditorium room configuration will use the four prototypes of the auditorium

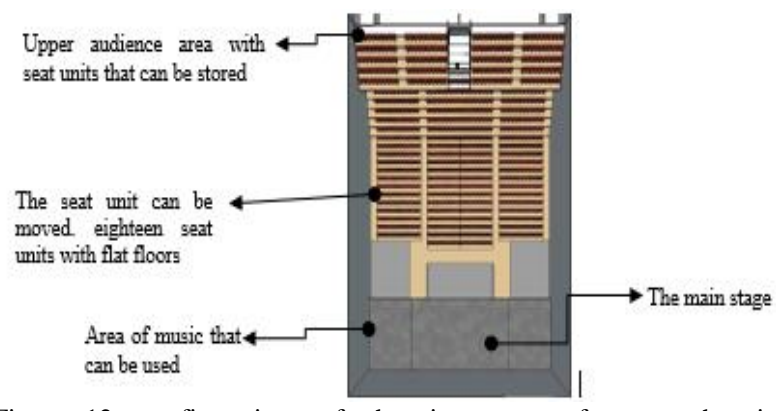

Figure 12. configurations of changing types of space, that is proscenium.

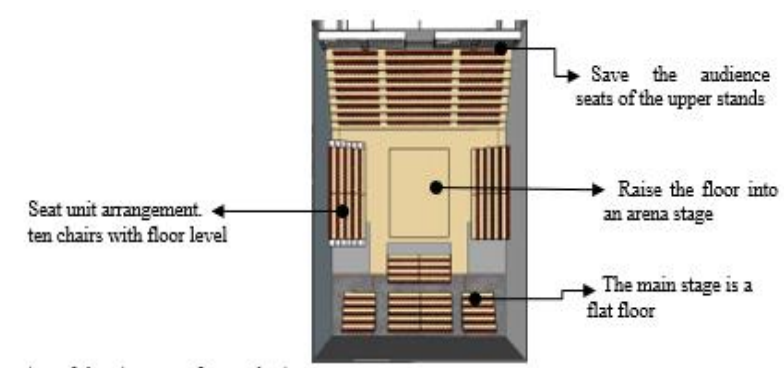

Figure 13. configurations of changing types of space, that is arena.

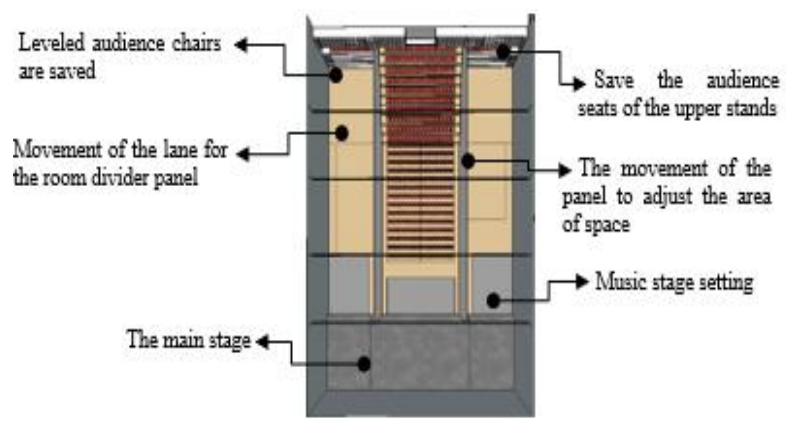

Figure 14. configurations of changing types of space, that is endstage.

or concert hall: square, horseshoe, fan, and hexagon [6]. In the basic rectangular shape plan, there is a intense sound interreflection between parallel sidewalls, while the fan shape, the rear auditorium wall automatically generated as a concave curved surface, which results in the echo of focus returning to the stage. In the prototype of horseshoes, which are favorite in theaters, not much recommend it for music; when enlarged enough to achieve satisfactory echo time, the reflection pattern becomes poor, there is a focus problem associated with the concave back wall. Then for the basic shape of the hexagon elongation offers a compromise with the visual benefits of the fan shape and the acoustic benefits of the reverse display and need to do some adjustment to the room.

From the above explanation, the use of the basic form of the auditorium focused on the rectangular shape. This is due to the acoustic quality and rectangular shape makes it a change in the configuration space. Figure 1 shows the changes that can occur in a square room.

The East Java traditional art auditorium supports various types of activities with different performance and scale of events, so the main hall tends to have a set of features that must be adaptable. Flexibility in space forms several forms of adaptation that can be done to meet the needs of traditional arts in East Java by serving three configurations, that is 
The $6^{\text {th }}$ International Seminar on Science and Technology (ISST) 2020

July $25^{\text {th }} 2020$, Institut Teknologi Sepuluh Nopember, Surabaya, Indonesia

Table 3 .

The sound source in the auditorium is based on the type of dance and drama.

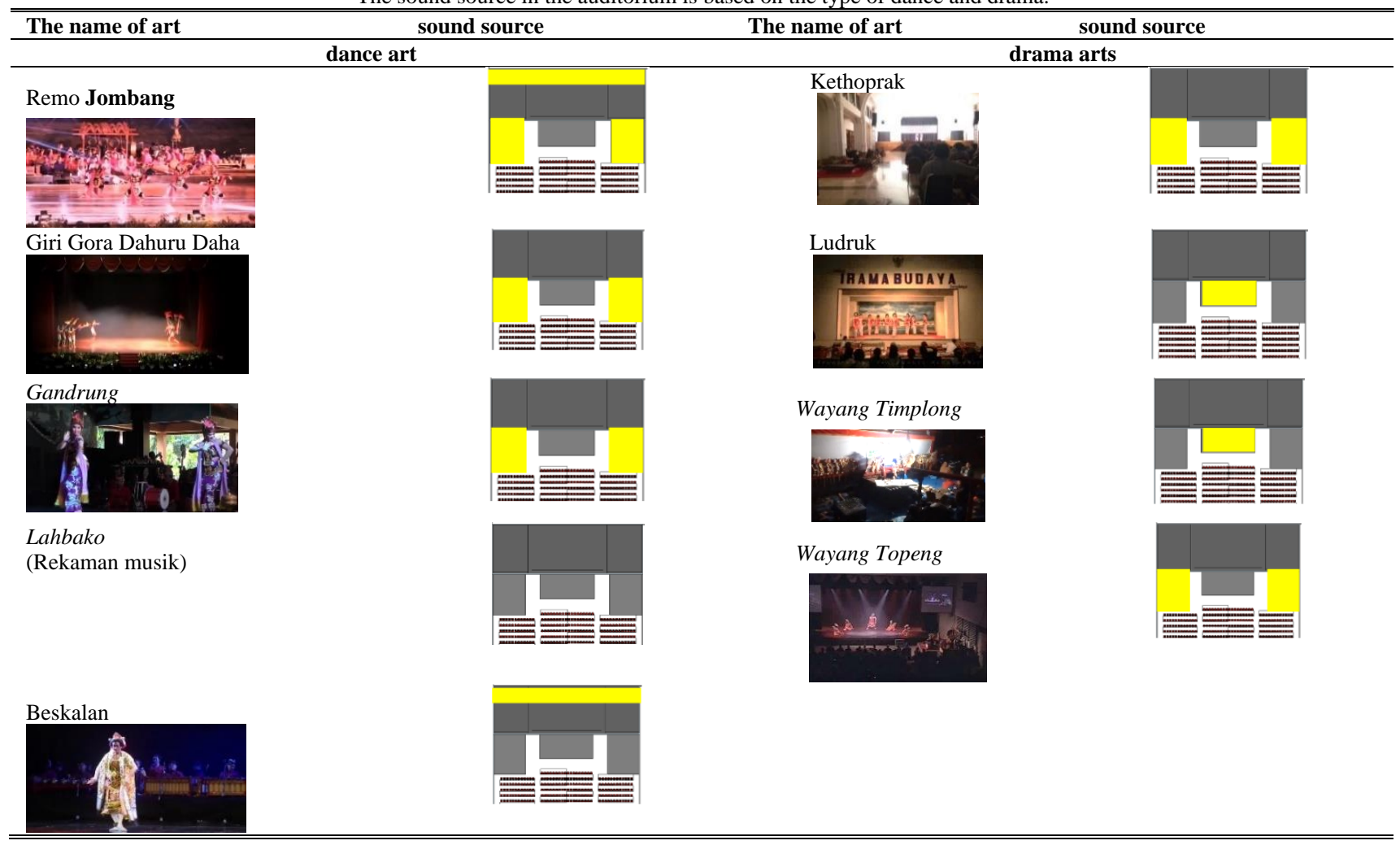

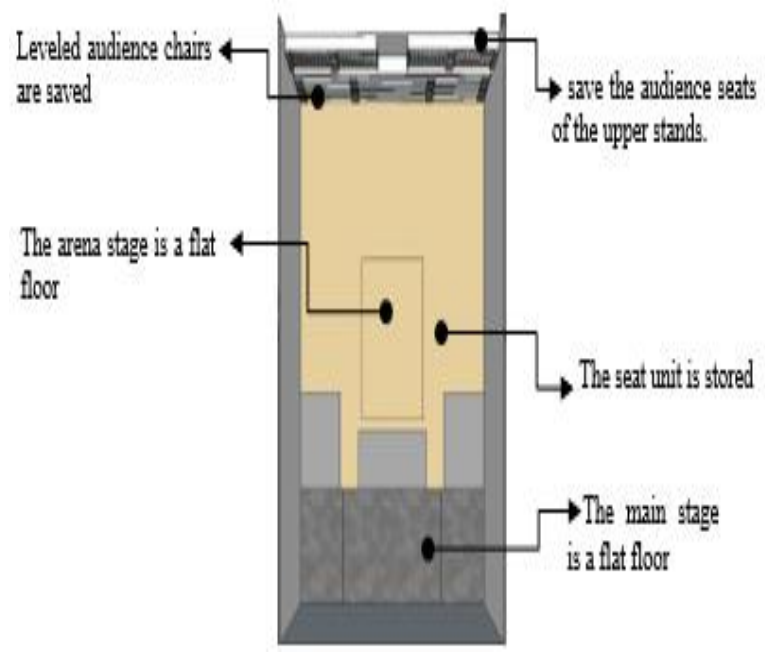

Figure 15. configurations of changing types of space, that is a flat floor.

Endstage, arena, and proscenium. Here are some flexibility that will be done to achieve the configuration of the space:

\section{1) Stage Flexibility and Stage Music}

From the analysis of the needs and location of musicians in each performance, there are four configurations needed that is (Figure 2):

1. Flat music stage needs,

2. Music stage $\mathrm{C}$ requirements (downstage),

3. Music stage B requirements (stage).

4. The need for stage music A (Stage).

The flexibility of changing the stage type can be done using the Hydraulic system as shown in Figure 3, to raise and lower the stage to a flat floor.

\section{2) Flexibility of Visiting Capacity}

To achieve the need for an area to accommodate the number of spectators, adaptations made to the auditorium are: closing the stands when not in use (Figure 4), through the use of curtains, screens, or turning off lighting, and movement of large-scale architectural elements, such as ceilings or walls that can go forward and backward (Figure 5 and 6).

\section{3) Seating Unit Flexibility}

The flexibility of the seating unit in the auditorium is that the seat block can stretch,and can fold back to make a linear wall unit flat when stored (Figure 9). Besides, other types of seating unit flexibility, namely the seating unit can be moved, rotated, and adjusted according to the kind of staging that will perform. This displacement of the seat unit applies the flexibility method, which is movable. The mobility of the seating unit allows large seating blocks to be moved from the auditorium when not placed inside the auditorium. This unit will move to the storage room under the auditorium by using a stage aid that can move as a floor elevator. the flexibility of the exact sit unit as in Figures 7 and 8.

\section{4) Flexibility of Acoustic Elements}

Flexibility in the auditorium must also consider the room acoustics. To achieve the desired acoustics in each configuration that can be achieved by adaptation of ceiling elements that can change the shape to adjust to the type of performance. Then the strategy of moving the hall wall panel elements can also be carried out so that the acoustic distribution in the space can be arranged evenly. The movement of these elements can be adapted to the needs and has several configurations that can be selected according to 
The $6^{\text {th }}$ International Seminar on Science and Technology (ISST) 2020

July $25^{\text {th }} 2020$, Institut Teknologi Sepuluh Nopember, Surabaya, Indonesia

the type of staging (Figure 10). Table 3 is a type of art with the direction of the sound source.

\section{5) Wall Panel Flexibility}

The flexibility of the wall panel allows the ability of the hall space can arrange into one small room or a larger one (Figure 11). Panel processing has the virtue of producing space for staging areas that require little or more breadth and capacity. The movement of the wall panels utilizes a rail system so that the movement of the wall panels will be easier and can be done automatically.

\section{6) Adaptation Hall}

Flexibility in the form of space adaptation has several forms of adaptation that can meet the needs of traditional arts in East Java by serving 4 configurations of changing types of space, that is endstage, arena, proscenium, and flat floor (Figurs 12-15).

\section{CONCLUSION}

From the results of the analysis, it has been concluded that an auditorium can adapt to many types of traditional East Javanese art activities that have different types of performances using the flexibility method. Some flexibility methods that can be used by the auditorium to be able to serve every change of activity are adaptable and movable from the interior elements of the room. From several methods of flexibility in the art space in his book Theater Building a Design Guide (strong, 2010), the auditorium that houses the activities of East Java art can apply several methods but by developing according to the needs of traditional art in East
Java, namely:(1)Top-level closure (tribune hall) when not in use; (2)Movement of large-scale architectural elements, such as moving ceilings or forward and backward wall structure movements; (3)seating units that can be reduced and added by folding or storing the seating unit; (4)flexibility of music players and the stage area that can adjust to the floor lift system; (5)Adjustable acoustics with ceiling and wall panels which have configurations that can be set and selected.

In this study, there are several points that still have shortcomings in detail and can develop further so that the changes and configurations needed can be clearer.

\section{ACKNOWLEDGMENT}

Thank you to the East Java art observers who have provided knowledge about the types of East Java arts and how the art process takes place, and all the information relating to the performance of East Java arts, where information and explanations helped in the course of this research.

\section{REFERENCES}

[1] Groat, L., \& Wang, D. (2013) Architectural Research Methods (Second Edition), New Jersey: John Wiley \& Sons, Inc.

[2] Kronenburg, Robert. (2007) Flexibility Architecture, Laurence King: London, UK.

[3] Thomas, Susan, p. (2013) Building Flexibility: The Extend to Which the Concept Needs to be Integrated Into Today's Design Process, Leeds Beckett University.

[4] Strong, Judith. (2010) Theatre Building a Design Guide, Routledge, Canada.

[5] Barron, Michael. (1993) Auditorium Acoustics and Architectural Design, Spon Press, Canada.

[6] Leitermann, Menurut. (2017) Theater Planning: Facilities for Performing Arts and Live Entertainment, Routledge, New York. 